\title{
THE RENIN/ANGIOTENSIN SYSTEM
}

\author{
M.R. LEE \\ Department of Medicine, University of Leeds, \\ Martin Wing, General Infirmary, Leeds LS1 3EX
}

The renin/angiotensin/aldosterone system occupies a central place in the physiological control systems for the regulation of total body sodium and in turn the volume of the extracellular fluids. Many therapeutic agents can affect renin, or other components of the system and it is important therefore for the clinical investigator to have some knowledge of the methods used in its study. This need has become more acute recently with the production by the pharmaceutical industry of agents designed, either to antagonise the action of angiontensin II at its receptors or to inhibit the action of the enzyme which converts angiotensin I into angiotensin II (the converting enzyme, dipeptide hydrolase or peptidyl dipeptidase). This process of development has culminated recently in the release of captopril the first generally available inhibitor of the converting enzyme.

\section{Components of the system}

The main components of the renin/angiotensin system are shown in Figures $1 \mathrm{a}$ and $1 \mathrm{~b}$. I think it will be generally helpful to consider two facets of the system:

(a) Renin is a proteolytic enzyme acting specifically on a Leu-Leu bond in a large molecular weight substrate. This starts the process which generates small peptides of varying physiological activity. Finally the small peptides are broken down to molecules which contain no more than six amino-acid residues and are physiologically inactive.

(b) In model terms the system is effectively a pressure-to-volume transducer. The juxtaglomerular cells of the afferent arteriole, which are the source of renin, respond to stretch in the arteriole and have been called the renal baroreceptor (Figures $1 \mathrm{~b}$ and 4 ). If blood pressure falls at this critical point in the circulation then renin is released and angiotensin is formed intrarenally. Sodium ions are then absorbed more avidly, both in the proximal tubule by the action of angiotensin and in the distal tubule by the action of aldosterone; the latter is released by the action of angiotensins II and III on the zona glomerulosa of the adrenal cortex.

Both the direct, renal and the indirect, adrenal
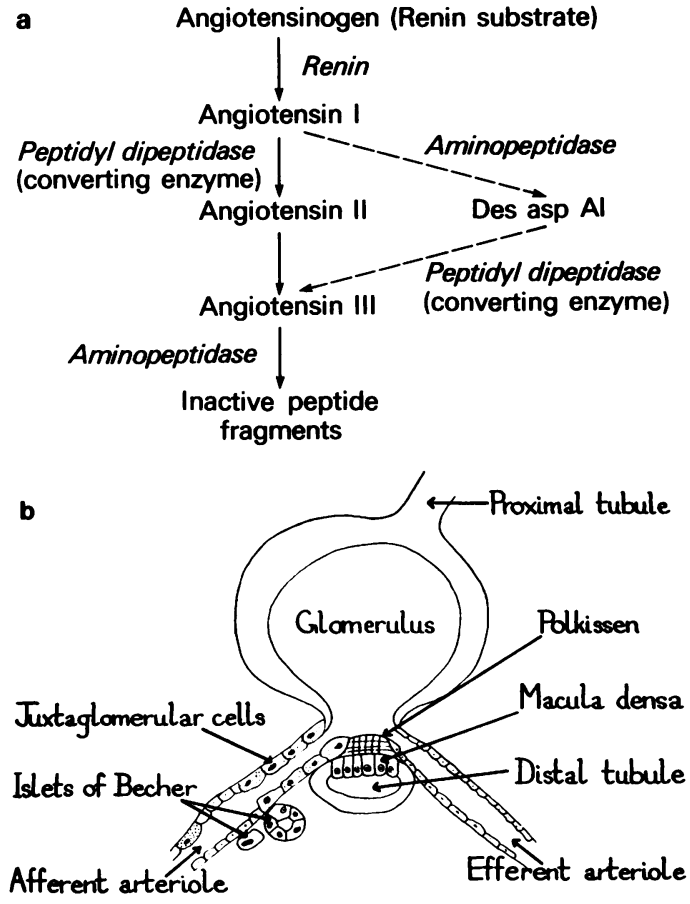

Figure 1 (a) The main components of the renin/ angiotensin system. Angiotensin $\mathrm{I}(\mathrm{AI})$ is converted to AII and AIII by the combined action of aminopeptidase and converting enzyme (peptidyl dipeptidase or dipeptide hydrolase).

(b) The microanatomy of the juxtaglomerular apparatus showing the source of renin namely the juxtaglomerular cells of the afferent arteriole (after Lee, 1969).

mechanisms serve to conserve sodium, to expand body fluid volumes and to raise the arterial blood pressure. The degree of stretch in the modified smooth muscles of the afferent arterioles (the juxtaglomerular cells) is thereby increased, renin release is inhibited and the long negative feedback loop is complete (Figure 4). There is also a short negative feedback loop whereby angiotensin II acts on specific peptide receptors on the surface of the juxtaglo- 
merular cell and inhibits further renin release. The short feedback loop becomes of critical importance when steps are taken to interrupt the renin/ angiotensin system pharmacologically. These include the use of compounds which cause an actual (or effective) fall in local or circulating angiotensin II concentration. As a result the short feedback loop to the juxtaglomerular cells is interrupted; renin release rebounds to a high level and in turn the concentration of angiotensin I (and in some cases angiotensin II) will rise. This reactive surge in the renin/angiotensin system will usually be physiologically impotent. It may however tend to oppose the change produced by the pharmacological inhibitor, or result in a marked rebound of arterial pressure if intravenous infusion of an inhibitor such as saralasin is stopped suddenly (see below and Figure 4).

\section{Drug induced changes}

Many drugs affect the renin/angiotensin system in a positive or negative way (Table 1 and Figure 4).

$\beta$-adrenoceptor agonists stimulate renin release as in the response to upright posture (see stimulation of renin secretion). Conversely $\beta$-adrenoceptor antagonists inhibit release.

Diuretics and vasodilators (including $\alpha$-adrenoceptor antagonists) activate the system by reducing extracellular fluid volume or arterial blood pressure. Similarly other agents which interfere at different stages in the feedback loops-aldosterone antagonists (spironolactone), converting enzyme inhibitors (captopril) and angiotensin II receptor blockers (saralasin)—stimulate renin release.

\section{Assay methods}

Most of the components of the renin/angiotensin system can now be measured with acceptable accuracy and reproducibility. However the methods available have distinct limitations which should be kept constantly in mind.

\section{Plasma renin activity}

No direct unit of mass for renin is available because of the lack of pure renin. As a result renin has to be measured by its angiotensin producing activity. Plasma (or tissue) is incubated under known conditions in the presence of renin substrate and the rate of production of angiotensin I (or angiotensin II) is measured. The result is expressed as mass of peptide per volume of incubation mixture per hour of incubation at a standard temperature (usually $37^{\circ} \mathrm{C}$ ). Thus a result might be expressed as $5 \mathrm{ng}$ angiotensin I per $\mathrm{ml}$ of incubation mixture per hour of incubation (Sealey \& Laragh, 1980). Initially, the product of the incubation, usually angiotensin $I$, was measured by its pressor effect on the pentobarbitone-anaesthetized ganglion-blocked rat (Lee, 1969) but this laborious method has now been replaced by radioimmunoassay.

The details of the assays vary widely, in terms of the $\mathrm{pH}$ of incubation, the duration of incubation, the ionic strength of the mixture and the nature of the inhibitors added to prevent the degradation of angiotensins I, II and III by the angiotensinase peptidase enzymes (Figures 1a and 2). The inhibitors of angiotensin breakdown used include ethylene diamine tetraacetic acid (EDTA), 8-hydroxyquinoline, di-

Table 1 Drugs which influence the renin/angiotensin system

\begin{tabular}{|c|c|c|}
\hline & \multicolumn{2}{|c|}{ Plasma renin activity } \\
\hline$\alpha$-adrenoceptor agonists & & $\downarrow$ \\
\hline antagonists & $\uparrow$ & \\
\hline$\beta$-adrenoceptor agonists & $\uparrow$ & \\
\hline antagonists (including labetalol) & & $\downarrow$ \\
\hline Angiotensin II antagonists (saralasin) & $\uparrow$ & \\
\hline Centrally acting hypotensives (clonidine, methyldopa) & & $\downarrow$ \\
\hline Converting enzyme inhibitors (captopril) & $\uparrow$ & \\
\hline Didretics & $\uparrow$ & \\
\hline Glucagon & $\uparrow$ & \\
\hline Glucocorticoids & $\uparrow$ & \\
\hline Mineralo sorticoid agonists (including carbenoxolone/liquorice) & & $\downarrow$ \\
\hline antagonists (spironolactone) & $\uparrow$ & \\
\hline Oestrogens (including combined contraceptive steroids) & $\uparrow$ & \\
\hline Prostaglandin synthetase inhibitors & & $\downarrow$ \\
\hline Vasodilators & $\uparrow$ & \\
\hline
\end{tabular}


mercaprol and phenylmethylsulphonylfluoride. Most inhibitor mixtures include EDTA and as a result converting enzyme, a zinc metallopeptidase, is also inhibited by the removal of its zinc prosthetic group. The product of incubation is therefore angiotensin I and the antibody for its detection must be directed against this peptide specifically.

Incubation of the renin/substrate mixture should take place at the optimum pH of 5.5 to 5.7 , without dilution, in the presence of antibacterial substances, such as neomycin and inhibitors of angiotensin I degradation. Under these conditions higher rates of generation of angiotensin I are achieved than with many commercial kits, thus making the measurement of low levels of renin activity more accurate (Sealey \& Laragh, 1980).

The term plasma renin activity describes the result of incubating plasma with its own inherent content of substrate; such methods are influenced both by the amount of renin and the amount of substrate. The term plasma renin concentration is also used to indicate the amount of angiotensin generated when a large excess of heterologous substrate is added to ensure zero order kinetics (Schambelan \& Stockigt, 1979). A third term, plasma renin reactivity describes the amount of angiotensin generated in vitro in response to a standard amount of renin and will reflect the presence of accelerators (or inhibitors) of the renin reaction (Kotchen et al., 1976).

\section{Prorenin}

Renin exists in human plasma in both an active form and an inactive form. The inactive form has come to be called prorenin and can be converted to classical renin either by storage at -5 to $+5^{\circ} \mathrm{C}$ or by treatment with acid (Sealey, Atlas \& Laragh, 1980). In order to avoid conversion of prorenin to renin, speed in handling samples is essential and they should be stored at temperatures below $-20^{\circ} \mathrm{C}$.

Many classical methods for plasma renin activity involve an acidification step and tend to overestimate plasma activity by causing some conversion of prorenin to renin (Brown et al., 1964; Skinner, 1967). This discrepancy can become important when attempts are made to stratify patients into high, low and normal renin groups; different methods in different laboratories are not comparable and produce different percentages of patients in the subgroups.

Total renin activity (prorenin plus renin) is determined by incubation of the plasma sample at $\mathrm{pH} 5.7$ and $37^{\circ} \mathrm{C}$ following previous incubation at $\mathrm{pH} 7.4$ and $-5^{\circ} \mathrm{C}$ for 4 days. Active renin is determined by incubation at $\mathrm{pH} 5.7$ and $37^{\circ} \mathrm{C}$ without the prior $-5^{\circ} \mathrm{C}$ stage. Prorenin is a calculated activity equal to total renin minus active renin (Atlas et al., 1977).

The relative proportions of prorenin and renin vary widely in different patients. Usually the concentra- tions of both forms of the enzyme move in parallel if the patient is depleted of sodium by dietary means or given an oral diuretic. In contrast propranolol or clonidine can produce an increase in prorenin concentration but a fall in concentration of active renin (Atlas et al., 1977).

The error in renin estimation, the variable conversion of prorenin to renin and the tremendous intraindividual variation in $24 \mathrm{~h}$ urine output of sodium, all combine to invalidate renin/sodium profiling based on single determinations of plasma renin activity and single measurements of $24 \mathrm{~h}$ urine sodium output. It is not surprising therefore that a patient classified as having 'low' activity on one occasion may have 'normal' activity on another. Renin/sodium profiling can be of value but only where the subject is under conditions of strict sodium balance (Lee, 1981).

\section{Renin substrate concentration}

It is sometimes of importance to measure renin substrate concentration. This can be achieved by addition of an excess of partially purified human renin, adjustment of $\mathrm{pH}$ to 5.7 and incubation at $37^{\circ} \mathrm{C}$ for $6 \mathrm{~h}$ to ensure complete conversion of the substrate to angiotensin I which is measured by radioimmunoassay. Inhibitors of angiotensinase (and inescapably converting enzyme) must be present in the incubation mixture to ensure quantitative recovery of the generated angiotensin I. Using such methods it has been possible to demonstrate increased plasma renin substrate concentration following oral combined contraceptive steroid use and also in certain clinical conditions such as Cushing's syndrome (Krakoff \& Eisenfeld, 1977).

\section{Angiotensin converting enzyme}

Converting enzyme activity has now become a matter of some importance with the production of clinically useful inhibitors such as captopril. Measurement of this activity in plasma is also diagnostically useful when sarcoidosis is suspected as the levels are uniformly elevated (Lieberman, 1975).

The original methods were based on adding labelled or unlabelled angiotensin I to plasma and following its conversion to angiotensin II. Separation of angiotensin II from unchanged angiotensin I is difficult and not altogether successful. Therefore synthetic peptides have been developed which can be hydrolysed by the converting enzyme. These include carbobenzoxy-Phe-His-Leu; CBZ-Pro-Phe-His-Leu; Hippuryl-His-Leu and several others (Figure 2; Piquilloud, Reinharz \& Roth, 1970; Cushman \& Cheung, 1971).

The principle of these assays can be illustrated as follows:

Hippuryl-His-Leu is split into hippuric acid and the 


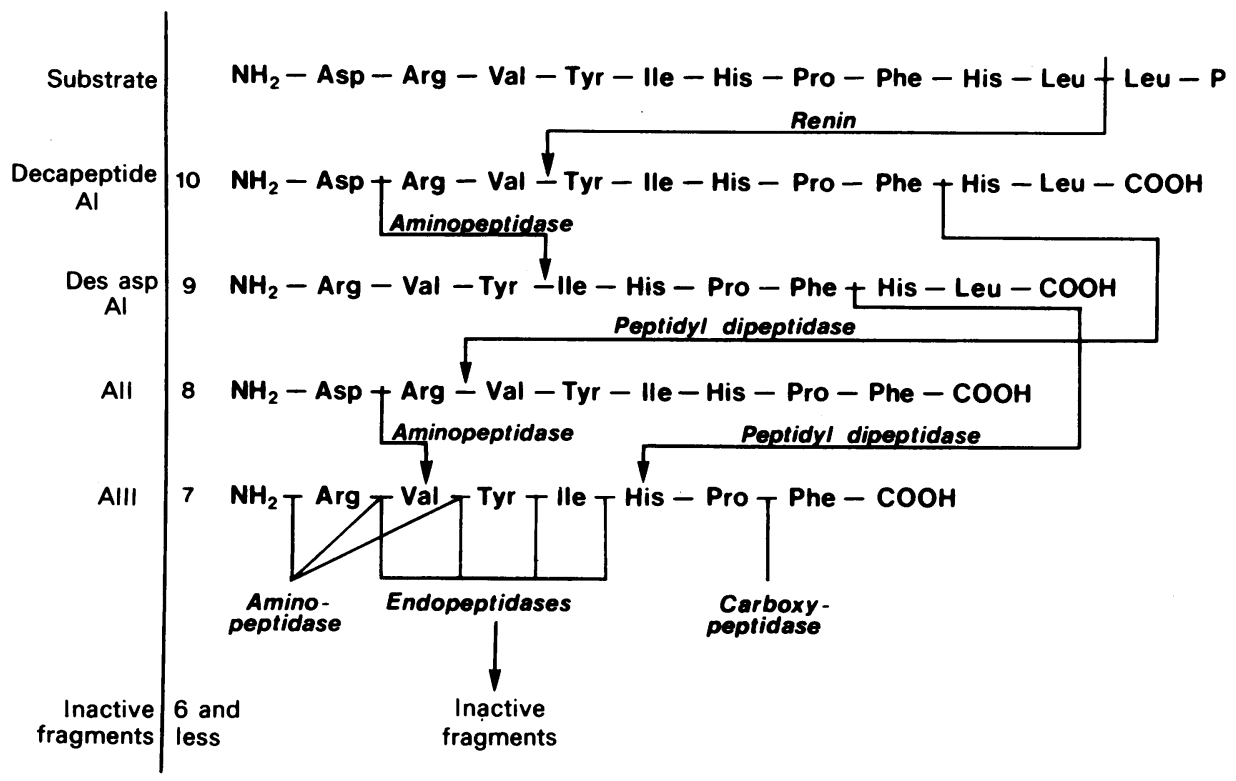

Figure 2 The peptides of the renin/angiotensin system. Angiotensin I and its Des-Asp derivative are converted into the 8 and 7 member peptides on the removal of the His-Leu dipeptide by converting enzvme (peptidyl dipeptidase or dipeptide hydrolase).

dipeptide His-Leu. The hippuric acid can then be estimated either by spectrophotometry or fluorimetry. The synthetic peptide is resistant to attack at the N-terminal position by aminopeptidases. Determinations are carried out both in the presence and the absence of chloride ions which are mandatory for converting enzyme activity. This confirms that the hydrolytic activity is in fact due to the specific action of the converting enzyme (Oparil, 1977).

\section{Stimulation of renin secretion}

It is no longer sufficient to determine plasma renin activity in peripheral venous blood solely under ambient conditions. The minute to minute, hour to hour variation in renin release from the juxtaglomerular cells results in wide variation in random plasma renin activity. The responsiveness of the system must be established by dynamic testing. The usual stimuli employed are dietary sodium restriction, assumption of the upright posture or intravenous frusemide.

\section{Sodium restriction}

The reduction of intake below $20 \mathrm{mmol}$ per day results in a prompt increase in renin secretion and an increased adrenal secretion of aldosterone. Nephrectomy or administration of angiotensin antagonists block the aldosterone secretory response in dogs subjected to dietary sodium deprivation (Davis, Ayers \& Carpenter, 1961; Davis \& Freeman, 1976; Stephens et al., 1977). Plasma aldosterone levels for any level of angiotensin II are higher during sodium depletion than during direct infusion of the octapeptide (Boyd et al., 1972); this may be due to an increase in the number of specific angiotensin II receptors on the adrenal glomerulosa cell (Douglas \& Catt, 1976).

\section{Change in posture}

When man stands upright there is a prompt increase in plasma renin activity and plasma aldosterone. This respor $s:$ is associated with sympathetic discharge and the activation of $\beta$-adrenoceptors on the juxtaglomerular cells; it is part of the integrated response which maintains blood pressure on standing up. When the subject is sodium replete the postural response is probably of less importance, than in the sodium depleted state, where the activity of the renin/ angiotensin system is crucial. When a converting enzyme inhibitor is administered in the sodium depleted state there is a marked lowering of blood pressure (Haber et al., 1975; Samuels et al., 1976). 


\section{Intravenous frusemide}

In view of the difficulties associated with the outpatient use of low sodium diets a useful alternative procedure has been adopted using intravenous frusemide $40-80 \mathrm{mg}$ and measuring the plasma renin response 30 to 90 minutes afterwards. Usually plasma renin activity will double or treble in this time if the renin axis is normal (Williams \& Dluhy, 1977).

\section{Renal ischaemia}

The ratio of renin levels between the affected and contralateral kidneys in renovascular hypertension is usually a more reliable index of renal ischaemia than the absolute level of renin on the affected side. A ratio of 1.5 or greater will forecast a postoperative improvement in blood pressure if surgery is technically successful (Stockigt et al., 1972).

The patient should be studied after a period of maintained recumbency to ensure basal conditions of renin secretion. After sampling from both renal veins and the inferior vena cava, various stimulation tests can be applied; these include upright tilting (Michelakis et al., 1969), the administration of a vasodilator such as diazoxide (Stockigt, Higgs \& Sacharias, 1976) or an angiotensin converting enzyme inhibitor ( $\operatorname{Re}$ et al., 1978). Renin levels on the affected side often increase two to threefold within 10 to $30 \mathrm{~min}$ and the ratio may increase substantially when compared with the basal unstimulated state.

\section{Interference from drug therapy}

When concurrent drug therapy is liable to interfere (Table 1) the only secure counsel is to withdraw the drug, under supervision, before evaluating the system. This withdrawal may provoke dangerous surges in blood pressure and cannot always be justified on ethical grounds, unless radical renal or renal arterial surgery is contemplated. If hypotensive treatment needs to be continued then guanethidine would appear to be the drug of choice as this adrenergic neurone blocker seems to have only minor effects on renin levels (Lowder \& Liddle, 1975).

The common offenders causing confusion regularly in the investigation of the renin/angiotensin system are listed in Table 1 . The mechanisms of action have generally been described earlier; glucocorticoids and oestrogens act indirectly by increasing renin substrate concentration. Spironolactone is a potent cause of difficulty as the effect may persist for several months (Lowder \& Liddle, 1974).

$\beta$-adrenoceptor antagonists are notorious for suppressing plasma renin activity and this has resulted in false renal vein renin ratio tests. Liquorice derivatives (and carbenoxolone) have given rise to a mistaken diagnosis of primary aldosteronism and even surgical exploration of the adrenals. The use of prostaglandin synthetase inhibitors has resulted in a failure of usual hypotensive therapy, together with suppressed plasma renin activity, again a recipe for serious errors in differential diagnosis.

The only reasonable advice to the investigator faced with this multiplicity of interactions is caveat emptor! Let the buyer beware! Always suspect interference from drugs in unexplained problems with the renin/angiotensin system.

\section{Screening methods}

Raised plasma renin activity may be inferred without assay from the blood pressure response to the administration of certain peptides or analogues.

\section{Intravenous infusion of angiotensin II}

This test was first introduced by Kaplan \& Silah (1964) and was based on the premise that if endogenous circulating angiotensin II levels were high then the patient should be resistent to infused exogenous peptide. Unfortunately the test proved both dangerous and of little value (Breckenridge, 1965) and has fallen into disrepute in general medicine.

However it has recently been revised by Gant and his coworkers in the United States as a method of forecasting, in pregnancy, those women who will develop preeclampsia (Gant et al., 1974). The basis on which the test works is not fully elucidated. Gant \& Worley (1980) suggest that in the absence of a vasodilator material, perhaps a prostaglandin, the peripheral arterioles become sensitized to exogenous angiotensin II. The test should only be performed in hospital under controlled conditions where maternal blood pressure, together with maternal and foetal heart rate, can be monitored closely.

\section{Intravenous infusion of saralasin}

Saralasin (1-Sarcosine-8-Ala-angiotensin II) was introduced in 1971 and thought initially to be a pure competitive antagonist of angiotensin II (Figures 3 \& 5). Brunner and his coworkers (1973) were able to show that marked depressor effects were obtained on the blood pressure of patients with high renin hypertension. A problem arose almost immediately; some patients with renal artery stenosis diagnosed by renal vein renin assay showed a negative response to saralasin - a false negative response (Thomas, Ball \& Lee, 1977). Worse was to follow. In an extensive study Case and his colleagues (1976) tested the arterial blood pressure of patients in the seated position, not receiving any medication. Saralasin lowered blood pressure in high renin patients but in low renin patients, with normal dietary sodium 


$$
\begin{aligned}
& \text { Sar - Arg - Val - Tyr - Val - His - Pro - Ala } \\
& \text { Saralasin } \\
& \text { <Glu - Trp - Pro - Arg - Pro - Gln - lle - Pro - Pro } \\
& \text { Teprotide }
\end{aligned}
$$

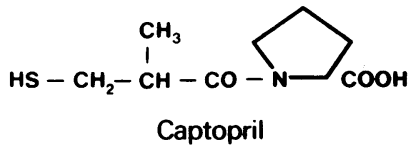

Figure 3 Structure of saralasin, teprotide and captopril, inhibitors of the renin/angiotensin system-for site of action see Figure 4. < Glu represents pyroglutamate.

intake, blood pressure rose during saralasin infusion. In all patients studied there was a close relationship between the pretreatment level of renin activity and the change in diastolic blood pressure. The point of zero change was equivalent to a renin activity of approximately $4 \mathrm{ng}$ angiotensin $\mathrm{I} \mathrm{ml}^{-1} \mathrm{~h}^{-1}$ (Figure 5). At renin activities below this level saralasin tended to increase blood pressure. In other words, below $4 \mathrm{ng}$ angiotensin $\mathrm{I} \mathrm{ml}^{-1} \mathrm{~h}^{-1}$, saralasin acted as an agonist in raising blood pressure; it is a partial agonist at angiotensin II receptors. This disappointing development together with the description of dangerous hypotensive and hypertensive reactions had led to the virtual abandonment of saralasin as a diagnostic or therapeutic agent (Case, 1980).

\section{Intravenous infusion of teprotide}

During the last fifteen years a separate development has taken place in the search for an inhibitor of the renin/angiotensin system. A nonapeptide has been isolated from the venom of the South American pit viper (Bothrops jararaca) which proved to have the structure shown in Figure 3 (Cheung \& Cushman, 1973). This peptide, now known as teprotide (SQ 20, 881) abolishes the pressor activity of angiotensin I,

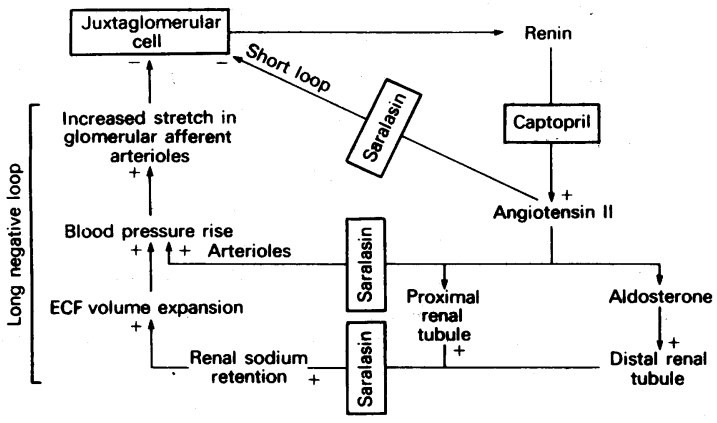

Figure 4 The long and short negative feedback loops from angiotensin II to the juxtaglomerular cell.
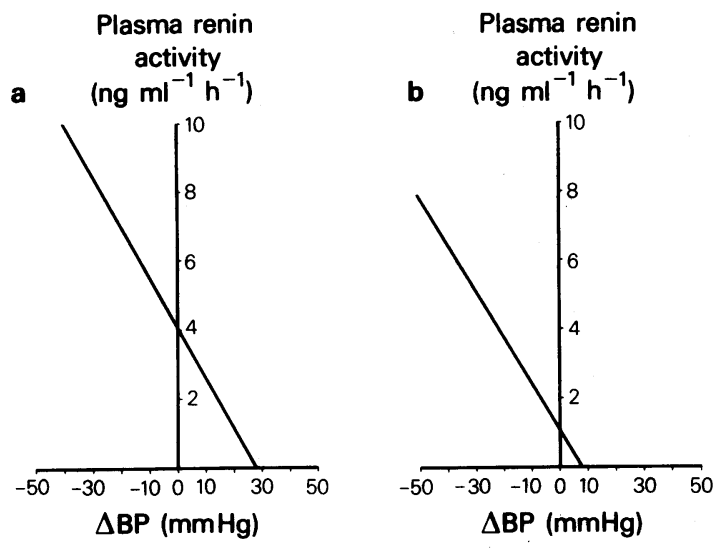

Figure 5 The change in diastolic blood pressure produced by (a) intravenous saralasin or by (b) oral captopril related to the patient's initial plasma renin activity (redrawn with modifications from Case, 1980). At renin activity levels below $4 \mathrm{ng}$ angiotensin $\mathrm{I} \mathrm{ml}^{-1} \mathrm{~h}^{-1}$, saralasin (a partial angiotensin agonist) produces a rise in blood pressure. This effect is not seen with captopril.

augments the vasodepressor activity of bradykinin and lowers blood pressure in some animal models of renovascular hypertension (Engel et al., 1972). At intravenous doses of up to $1 \mathrm{mg} / \mathrm{kg}$ teprotide produces a pronounced lowering of blood pressure in patients with renovascular or malignant hypertension (Case, Wallace et al., 1980). In contrast to saralasin, patients with very low plasma renin activity have no pressor response to teprotide showing a lack of agonist activity in the nonapeptide. The main problem with teprotide is that although it is an effective converting enzyme inhibitor and provides a useful preliminary screening method for renin activity it has to be given intravenously, and as such, needs constant infusion equipment and close patient observation.

\section{Oral captopril}

In 1977 Ondetti, Rubin \& Cushman reported the design and synthesis of captopril, (D-3-mercapto-2methylpropanoyl-L-proline SQ 14,225, Figure 3) an orally bioavailable, converting enzyme inhibitor. The compound has a rapid onset of hypotensive action; the blood pressure falls within 90 min of the first oral dose. The extent of the blood pressure fall parallels the pretreatment renin activity closely (Figure 5). There is also an immediate reduction in plasma aldosterone, increased sodium loss in the urine and potassium retention in the kidney accompanied by a rise in plasma potassium (Case, Atlas et al., 1980; Case 1980).

Captopril is given to the patient in the sitting 
position. All drugs should have been discontinued and the patient should be receiving a normal dietary sodium intake. Most patients with renovascular hypertension $(>95 \%)$ sustain a diastolic blood pressure fall of $10 \%$ or more (positive response) and a reactive rise in plasma renin activity to more than 14 ng angiotensin $\mathrm{I} \mathrm{ml}^{-1} \mathrm{~h}^{-1}$ (Case, 1980; see also Figure 4). Patients with essential hypertension may show a similar fall in diastolic blood pressure but not the same compensatory rise in plasma renin activity.

Case (1980) has suggested that the oral captopril test can be used as a basis for the selection of effective treatment for hypertension. Patients having a positive response will usually respond to $\beta$-adrenoceptor blockade or continued oral captopril. In contrast, patients with a negative response will usually be low renin hypertensives. Most of these will show an adequate blood pressure fall in response to oral diuretic therapy. Those who do not should then undergo a second test which will identify diuretic induced renin dependency. A positive test at this stage would be an indication for an antirenin agent; whereas a negative response would suggest that an $\alpha$ adrenoceptor blocking agent or peripheral vasodilator should be the next choice in the stepwise graded treatment of the raised blood pressure.

\section{Conclusions}

Considerable progress has been made on the renin/ angiotensin system in the last ten years in two main directions:

(1) the methods for the assay of the important components of the renin/angiotensin system have become firmly established. The advent of radioimmunoassay for angiotensin I has brought techniques for determination of plasma renin activity well within the compass of the average clinical investigative laboratory.

(2) the development of compounds that will interfere with the renin/angiotensin system has culminated in the development of the powerful, orally effective, converting enzyme inhibitor captopril. This compound should prove to be extremely valuable both in the investigation and treatment of renovascular and essential hypertension.

The availability of modern methods of investigation and treatment of hypertension will generate several major benefits for the individual with raised arterial blood pressure. The selection of that small minority of patients who merit invasive procedures for the investigation of renovascular hypertension should be rendered more reliable by the oral captopril test. Moreover the tailoring of hypotensive treatment for the difficult clinical problem should become easier with the availability of converting enzyme inhibition. The advent of captopril and other impending developments may signal the demise of refractory or resistant hypertension. I suggested more than ten years ago (Lee, 1969) that the introduction of radioimmunoassay techniques would revolutionise the study of the renin/angiotensin system. This has indeed proved to be the case. Measurements that needed days can now be completed in hours. The new methods, taken together with the analytic (and synthetic) effort of the natural products chemist, have provided a secure base from which further expeditions can be made into the terra incognita of essential and renal hypertension.

I thank Mr Howard Starkey for the Figures. Figure 5 has been redrawn from Case (1980) and is reproduced by kind permission of the author and the Editorial Board of Cardiovascular Reviews and Reports.

\section{References}

ATLAS, S.A., LARAGH, J.H., SEALEY, J.E. \& MOON, C. (1977). Plasma renin and 'prorenin' in essential hypertension during sodium depletion, beta-blockade and reduced arterial pressure. Lancet, ii, 785-788.

BRECKENRIDGE, A. (1965). Angiotensin infusion test. Lancet, ii, 209-211.

BROWN, J.J., DAVIES, D.L., LEVER, A.F., ROBERTSON, J.I.S. \& TREE, M. (1964). The estimation of renin in human plasma. Biochem. J., 93, 594-600.

BOYD, G.W., ADAMSON, A.R., ARNOLD, M., JAMES, V.H.T. \& PEART.W.S. (1972):The role of angiotensin II in the control of aldosterone in man. Clin. Sci., 42, 91-104.

BRUNNER, H.R., GAVRAS, H., LARAGH, J.H. \& KEENAN, R. (1973). Angiotensin II blockade in man by sar ${ }^{1}$-ala ${ }^{4}$ angiotensin II for understanding and treatment of high blood pressure. Lancet, ii, 1045-1048.
CASE, D.B. (1980). Antirenin drugs in diagnosis and treatment: An alternative to plasma renin activity measurements. Cardiovascular Rev. Rep., 1, 679-684.

CASE, D.B., ATLAS, S.A, LARAGH, J.H., SEALEY, J.E., SULLIVAN, P.A. \& McKINSTRY, D.N. (1980). Clinical experience with blockade of the renin/angiotensin aldosterone system by an oral converting enzyme inhibitor (Captopril). In Topics in hypertension. ed. Laragh. J.H..Chapter 36, pp 589-606. New York: Yorke Medical Books.

CASE, D.B., WALLACE, J.M., KEIM, H.J., SEALEY, J.E. \& LARAGH, J.H. (1976). Limitations and usefulness of saralasin, a partial competitive agonist of angiotensin II for evaluating the renin and sodium factors in hypertensive patients. Am. J. Med., 60, 825-836.

CASE, D.B., WALlACE, J.M., KEIM, H.J., WEBER, M.A., 
DRAYER, J.I.M., WHITE, R.P., SEALEY, J.E. \& LARAGH, J.H. (1980). Estimating renin participation in Hypertension: Superiority of converting enzyme inhibitor over saralasin. In Topics in hypertension, ed. Laragh, J.H. Chapter 35, pp 577-588. New York: Yorke Medical Books.

CHEUNG, H.S. \& CUSHMAN, D.W. (1973). Inhibition of homogeneous angiotensin converting enzyme of rabbit lung by synthetic venom peptides of Bothrops jararaca. Biochim. Biophys. Acta., 293, 451-463.

CUSHMAN, D.W. \& CHEUNG, H.S. (1977). Spectrophotometric assay and properties of the angiotensin converting enzyme of rabbit lung. Biochem. Pharmac., 20 , 1637-1648.

DAVIS, J.O., AYERS, C.R. \& CARPENTER, C.C.J. (1961). Renal origin of an aldosterone stimulating hormone in dogs with thoracic caval constriction and in sodium depleted dogs. J. clin. Invest., 40, 1466-1474.

DAVIS, J.O. \& FREEMAN, R.H. (1976). Mechanisms regulating renin release. Physiological Rev., 56, 1-56.

DOUGLAS, J. \& CATT, K.J. (1976). Regulation of angiotensin II receptors in the rat adrenal cortex by dietary electrolytes. J. clin. Invest., 58, 834-843.

ENGEL, S.L., SCHAEFFER, T.R., GOLD, B.I. \& RUBIN, P. (1972). Inhibition of pressor effects of angiotensin I and augmentation of depressor effects of bradykinin by synthetic peptides. Proc. Soc. exp. Biol. Med., 140, 240-244.

GANT, N.F., CHAND, S., WHALLEY, P.J. \& MACDONALD, P.C. (1974). The nature of the pressor responsiveness to angiotensin II in human pregnancy. Obstet. Gynecol., 43, 854-860.

GANT, N.F. \& WORLEY, R.J. (1980). Maternal Vascular Reactivity to Pressor Agents. In Hypertension in Pregnancy: Concepts and Management, pp. 11-36. New York: Appleton-Century-Crofts.

HABER, E., SANCHO, J., RE, R., BURTON, J. \& BARGER, A.C. (1975). The role of the renin/angiotensin/aldosterone system in cardiovascular homeostasis in normal men. Clin. Sci., 48, 49S-52S.

KAPLAN, N.M. \& SILAH, J.G. (1964). The angiotensin infusion test. New Engl. J. Med., 271, 536-541.

KOTCHEN, T.A., TALWALKER, R.T., MILlER, M.C. \& WELSH, J.C. (1976). Modification of renin reactivity by lipids extracted from normal, hypertensive and uremic plasma. J. clin. Endocrin. Metab., 43, 971-981.

KRAKOFF, L.R. \& EISENFELD, A.J. (1977). Hormonal control of plasma renin substrate. Circulation Res., 41 (suppl II). II-43-II 46.

LEE, M.R. (1969). Renin and Hypertension: a modern synthesis, pp 107-117. London: Lloyd-Luke Medical Publications.

LEE, M.R. (1981). Methods in clinical pharmacology: effects of drugs on sodium metabolism. Br. J. clin. Pharmac., 12, 103-109.

LIEBERMAN, J. (1975). Elevation of serum angiotensin converting enzyme (ACE) in sarcoidosis. Am. J. Med., 59, 365-372.

LOWDER, S.C. \& LIDDLE, G.W. (1974). Prolonged alteration of renin responsiveness after spironolactone therapy. New Engl. J. Med., 291, 1243-1244.
LOWDER, S.C. \& LIDDLE, G.W. (1975). Effects of guanethidine and methyldopa on a standardized test for renin responsiveness. Ann. int. Med., 82, 757-760.

MICHELAKIS, A.M., WOODS, J.W., LIDDLE, G.W. \& KLATTE, E.C. (1969). A predictable error in use of renal vein renin in diagnosing hypertension. Arch. int. Med., 123, 359-361.

ONDETTI, M.A., RUBIN, B. \& CUSHMAN, D.W. (1977). Design of specific inhibitors of angiotensin converting enzyme: new class of orally active antihypertensive agents. Science, 196, 441-444.

OPARIL, S. (1977). Angiotensin I converting enzyme and inhibitors. In Hypertension: Physiopathology and Treatment, eds. Genest, J., Koiw, E. \& Kuchel, O., pp 156-167. New York: McGraw-Hill.

PIQUILlOUD, Y., REINHARZ, A. \& ROTH, M. (1970). Studies on the angiotensin converting enzyme with different substrates. Biochim. Biophys. Acta, 206, $136-142$

RE, R., NOVELLINE, R., ESCOURROU, M-T., ATHANASOULIS, C., BURTON, J. \& HABER, E. (1978). Inhibition of angiotensin converting enzyme for diagnosis of renal artery stenosis. New Engl. J. Med., 298. 582-586.

SAMUELS, A.I., MILLER, E.D. Jr., FRAY, J.C.S., HABER, E. \& BARGER, A.C. (1976). Renin/angiotensin antagonists and the regulation of blood pressure. Fed. Proc., 35 , 2512-2520.

SCHAMBELAN, M. \& STOCKIGT, J.R. (1979). Clinical use of renin measurements. In Hormonal function and the kidney, pp 22-39. New York, Edinburgh and London: Churchill Livingstone.

SEALEY, J.E. \& LARAGH, J.H. (1980). How to do a plasma renin assay. In Topics in Hypertension, ed. Laragh. J.H. , pp 244-256. New York: Yorke Medical Books.

SEALEY, J.E., ATLAS, S.A. \& LARAGH, J.H. (1980). Occurrence and characteristics of a Prorenin like substance in human plasma. In Topics in Hypertension, ed. Laragh, J.H., pp 112-114. New York: Yorke Medical Books.

SKINNER, S.L. (1967) Improved assay methods for renin concentration and activity in human plasma. Circulation Res., 20, 391-402.

STEPHENS, G.A., DAVIS, J.O., FREEMAN, R.H., WATKINS, B.E. \& KHOSLA, M.C. (1977). The effects of angiotensin II blockade in conscious sodium depleted dogs. Endocrinology, 101, 378-388.

STOCKIGT, J.R., COLLINS, R.D., NOAKES, C.A., SCHAMBELAN, M. \& BIGLIERI, E.G. (1972). Renal vein renin in various forms of renal hypertension. Lancet, $i$. 1194-1198.

STOCKIGT, J.R., HIGGS, E.S. \& SACHARIAS, N. (1976). Diazoxide induced stimulation of renin release in renal vein renin sampling. Clin. Sci., 51, 235S-237S.

THOMAS, R.D., BALL, S.G. \& LEE, M.R. (1977). Failure of saralasin to predict a response to surgery in renovascular hypertension. Lancet, i, 724-726.

WILLIAMS, G.H. \& DLUHY, R.B. (1977). Regulation of renin/angiotensin/aldosterone axis in hypertension. In Hypertension, eds. Genest, J., Koiw, E. \& Kuchel, O., pp 293-312. New York: McGraw-Hill. 